\title{
Total protein, selected protein fractions and chemical elements in the colostrum and milk of mares (Short Communication)
}

\author{
ANGELIKA CIEŚLA, ROBERT PALACZ, JOLANTA JANISZEWSKA and DOROTA SKÓRKA \\ Department of Horse Breeding, West Pomeranian University of Technology, Poland
}

\begin{abstract}
The study material consisted of the colostrum and milk of five noble half-blood mares housed under the same environmental conditions. Colostrum samples were collected 24 $\mathrm{h}$ after foaling, whereas milk samples were taken five times, every 30 days, with the first sampling on lactation day 30 (1st month). In the samples were determined the concentrations of total protein, pre-albumins, albumins, $\alpha$ - and $\beta$-globulins, immunoglobulins and calcium (Ca), magnesium ( $\mathrm{Mg}$ ) and zinc $(\mathrm{Zn})$. The presence of pre-albumins was observed only in mare colostrum. Total protein concentration was at the same level in the colostrum and in the milk in the 1st lactation month, whereas protein fraction concentrations underwent dynamic changes during the 1st month of lactation. When compared to the values determined in the colostrum, the level of a-globulins increased 8 times during lactation, whereas that of immunoglobulins decreased almost 4 times. The highest concentrations of $\mathrm{Ca}, \mathrm{Mg}$ and $\mathrm{Zn}$ were found in mare colostrum, with a decrease in the concentration of all chemical elements in the 1st month of lactation, confirmed statistically in case of $\mathrm{Mg}$ and $\mathrm{Zn}$.
\end{abstract}

Keywords: mares, colostrum, milk, protein, chemical elements

\section{Zusammenfassung}

\section{Gesamteiweiß, ausgewählte Eiweißfraktionen und Makroelemente in Stutenkolostrum sowie -milch (Kurzmitteilung)}

Untersucht wurde Stutenkolostrum und -milch von 5 Halbblutstuten die unter gleichen Bedingungen gehalten wurden. Das Kolostrum wurde $24 \mathrm{~h}$ nach der Fohlengeburt, die Stutenmilch beginnend am 30. Tag nach der Geburt in monatlichen Abständen bis zum 5. Monat gemolken. In den Proben wurden folgende Inhaltstoffe erfasst: Gesamteiweiß, Präalbumin, Albumin, $\alpha$ - und $\beta$-Globulin, Immunoglobulin sowie die Mineralstoffkonzentration von Kalzium (Ca), Magnesium (Mg) und Zink (Zn). Präalbumin fand sich nur im Kolostrum. Während der Gesamteiweißgehalt im Kolostrum auf dem gleichen Niveau wie im ersten Laktationsmonat lag und bis zum 4. Monat wenig abnahm, veränderten sich die Anteile der einzelnen Eiweißfraktionen bis zum 5. Laktationsmonat erheblich. So erhöhte sich z.B. der a-Globulinspiegel um das achtfache während sich der Immunoglobulinspiegel um das vierfache verringerte. Die höchsten Ca-, Mg- und Zn-Gehalte fanden sich im Kolostrum und nahmen mit zunehmender Laktationsdauer ab.

Schlüsselwörter: Stuten, Kolostrum, Milch, Eiweiß, Makroelemente 


\section{Introduction}

In recent years, difficulties in assimilation of cow milk by children and adults have been more and more frequent. Therefore, a valuable initiative is to search for replacement products, the assimilability of which by human organism is better. The mare milk is commonly considered to be similar in its composition to the milk of woman and for that reason is better tolerated by human organism than that of cow. The milk of mare, like that of woman, belongs to the albumin type in respect of protein, composition, whereas that of cow and goat represents the casein type (MALACARNE et al. 2002, DANKÓW et al. 2006). However, the mare milk is not commonly available on the market in Poland, like for example goatss milk and its products. Large similarity of the woman and the mare milk is well promising as far as replacement of human maternal milk with the milk of mare in infant diet is concerned, which gives reasons for taking up studies on mare milk. The present study aimed at determining the concentration of total protein, selected protein fractions and $\mathrm{Ca}, \mathrm{Mg}$ and $\mathrm{Zn}$ in the colostrums and milk of mares in respective lactation months.

\section{Material and methods}

The study material consisted of the colostrum and milk of five noble half-blood mares housed under similar environmental conditions. Colostrum samples were collected $24 \mathrm{~h}$ after parturition, whereas milk samples were taken five times, every 30 days, with the first sampling on lactation day 30 ( 1 st month). Altogether, 5 colostrum and 25 milk samples were collected and analysed. In the analysed samples, total protein concentration was determined with Lowryss method, whereas protein fraction distribution was made with agarose gel electrophoresis (Cormay). Ca, Mg and Zn concentrations were assayed by inductively coupled plasma optical emission spectroscopy (ICP-OES), using an Optima 2000 DV apparatus (Perkin-Elmer Instruments, Norwalk, CT, USA), after prior mineralisation of samples in a high-pressure microwave mineralisation system (Anton Paar GmbH, Graz, Austria), using a standard procedure for milk included within the appliance software. The obtained data were analysed statistically using the repeated measures analysis of variance with Tukey's test (Statistica 7.0 software package).

\section{Results}

Table 1 presents mean total protein and selected protein fraction concentrations in mare colostrum and milk. The mean content of total protein in mare colostrum (Table 1) did not change significantly in the examined period. The highest level of total protein was observed in the 2nd month of lactation, whereupon its concentration decreased in the 5th month of lactation. Table 1 also presents protein fractions separated in the colostrum and milk of mares. The presence of pre-albumins was observed only in the colostrum of mares. The level of that fraction ranged in respective mares from 9.7 to $18.0 \%$. Among mare milk protein fractions, albumins and a-globulins prevailed quantitatively. The lowest mean level of albumins was found in the colostrum. The concentration of that fraction increased significantly in the 1st month of lactation, whereupon decreased in the 
4th month. The concentration of a-globulins was characterised by largest differences. In mare colostrum, the mean level of that fraction was significantly lower from the value determined in the 1st month of lactation, whereupon increased gradually in the 5th month. The mean concentration of $\beta$-globulins in mare colostrum changed to a small extend; its decrease was observed in the 2nd month of lactation, another increase in the 4th month and a drop in the 5th month. These changes were not confirmed statistically. The mean level of immunoglobulins in the examined milk decreased during lactation. In mare colostrum, mean immunoglobulin concentration showed a significant drop in the 1 st month of lactation and a successive decrease to the 5th month.

Table 1

Mean total protein and selected protein fraction concentrations in mare colostrum and milk

Durchschnittliche Gesamteiweiß- und ausgesuchte Eiweißfraktionkonzentration im Kolostrum und in den Stutenmilch

\begin{tabular}{|c|c|c|c|c|c|c|}
\hline $\begin{array}{l}\text { Lactation } \\
\text { stage }\end{array}$ & $\begin{array}{l}\text { Total protein } \\
(\mathrm{g} / \mathrm{l}) \\
\text { Mean } \pm \mathrm{SD} \\
\end{array}$ & $\begin{array}{c}\text { Pre-albumins } \\
(\%) \\
\text { Mean } \pm \text { SD } \\
\end{array}$ & $\begin{array}{c}\text { Albumins } \\
(\%) \\
\text { Mean } \pm \text { SD } \\
\end{array}$ & $\begin{array}{c}\text { a-globulins } \\
(\%) \\
\text { Mean } \pm \text { SD } \\
\end{array}$ & $\begin{array}{c}\beta \text {-globulins } \\
(\%) \\
\text { Mean } \pm \text { SD } \\
\end{array}$ & $\begin{array}{c}\text { Immuno- } \\
\text { globulins (\%) } \\
\text { Mean } \pm \text { SD }\end{array}$ \\
\hline Colostrum & $64.6 \pm 19.0$ & $13.0 \pm 4.4$ & $* 22.1 \pm 1.0$ & $* 5.5 \pm 0.8$ & $15.2 \pm 5.5$ & $* 44.2 \pm 2.4$ \\
\hline 1st month & $68.9 \pm 11.5$ & - & *37.6 1.6 & $* 30.3 \pm 5.8$ & $13.1 \pm 3.4$ & ${ }^{*} 19.1 \pm 4.6$ \\
\hline 2nd month & $73.0 \pm 17.6$ & - & $36.0 \pm 3.2$ & $38.0 \pm 2.5$ & $10.5 \pm 3.6$ & $15.4 \pm 2.3$ \\
\hline 3rd month & $62.3 \pm 12.4$ & - & $35.2 \pm 2.4$ & $38.8 \pm 1.1$ & $10.8 \pm 2.4$ & $15.8 \pm 2.6$ \\
\hline 4th month & $60.9 \pm 10.6$ & - & $32.9 \pm 1.3$ & $40.6 \pm 0.6$ & $11.7 \pm 2.9$ & $14.8 \pm 2.5$ \\
\hline 5th month & $46.9 \pm 7.9$ & - & $33.8 \pm 3.4$ & $43.5 \pm 1.3$ & $9.9 \pm 2.4$ & $12.9 \pm 3.4$ \\
\hline
\end{tabular}

* differences between samples from respective lactations stages significant at $P \leq 0.05, \quad$ SD standard deviation

Table 2

Mean $\mathrm{Ca}, \mathrm{Mg}$ and $\mathrm{Zn}$ concentrations in mare colostrum and milk ( $\mathrm{mg} / \mathrm{l})$

Durchschnittliche $\mathrm{Ca}-, \mathrm{Mg}$ - und $\mathrm{Zn}$-Konzentration im Kolostrum und in den Stutenmilch

\begin{tabular}{lccc}
\hline Lactation stage & Ca & Mg & Zn \\
Mean \pm SD & Mean \pm SD & Mean \pm SD \\
\hline Colostrum & $1088.5 \pm 199$ & $* 181.3 \pm 104$ & $* 5.1 \pm 4.5$ \\
1st month & $868.8 \pm 205$ & $* 57.1 \pm 15.0$ & $* 1.6 \pm 0.1$ \\
2nd month & $710.0 \pm 240$ & $53.8 \pm 14.6$ & $1.7 \pm 0.5$ \\
3rd month & $713.9 \pm 161$ & $50.9 \pm 5.5$ & $2.1 \pm 0.4$ \\
4th month & $657.1 \pm 137$ & $48.7 \pm 6.7$ & $2.5 \pm 0.7$ \\
5th month & $453.1 \pm 217$ & $40.4 \pm 11.3$ & $1.8 \pm 0.9$ \\
\hline
\end{tabular}

* differences significant at $P \leq 0.05$, SD standard deviation

Table 2 presents mean $\mathrm{Ca}, \mathrm{Mg}$ and $\mathrm{Zn}$ concentrations in the colostrum and milk of mares. As it results from the table, the colostrum of mares was characterised by highest concentrations of chemical elements discussed when compared with milk. Mean Ca concentration in mare colostrum decreased during lactation. Mean $\mathrm{Mg}$ concentration in mare colostrum exceeded over three times the mean concentration of $\mathrm{Mg}$ determined in the 1st month of lactation. During lactation, mean $\mathrm{Mg}$ concentration in milk decreased gradually. Like in case of $\mathrm{Ca}$ and $\mathrm{Mg}$, mean $\mathrm{Zn}$ concentration in the colostrum was decidedly higher when compared to mare milk, too. The mean concentration of that chemical element did not show however a regular downward trend during lactation. 


\section{Discussion}

As reported in the literature, total protein level in mare colostrum and milk differs greatly. Colostrum protein level is influenced among others by the time of its collection. PASQUINI et al. (2005) found that total protein level in the colostrum of mares on parturition day amounted to $93.61 \mathrm{~g} / \mathrm{l}$, while $12 \mathrm{~h}$ after parturition to $60.15 \mathrm{~g} / \mathrm{l}$. This is a similar value to that obtained in the present study for the colostrum collected $24 \mathrm{~h}$ after parturition. Lower total protein levels in mare colostrum were found by TISHNER et al. (1996) 12 and $24 \mathrm{~h}$ after parturition, i.e. 36.42 and $31.75 \mathrm{~g} / \mathrm{l}$, respectively. On the other hand, WŁODARCZYK-SZYDŁOWSKA et al. (2005) observed higher total protein values in the colostrum of Thoroughbred mares collected directly after parturition, i.e. $112.4 \mathrm{~g} / \mathrm{I}$ on average; similarly, CSAPÓ-KISS et al. (1995) also reported high total protein level in mare colostrum, i.e. $164.1 \mathrm{~g} / \mathrm{kg}$. DANKÓW et al. (2006) observed that total protein concentration in the colostrum of the Wielkopolski mares was 1.75 time higher $24 \mathrm{~h}$ after foaling than on the second day. PIESZKA (2005) found, in the milk of Arabian mares, that total protein concentration on the 2 nd day of lactation was $3.43 \%$, being the highest one, followed by a decrease to $2.09 \%$ on day 30. Other authors reported (CSAPÓ-KISS et al. 1995, MALACARNE et al. 2002, DANKÓW et al. 2006) that total protein level in mare milk ranges from 1.7 to $3 \%$. As it results from Table 1, total protein concentration in the milk of mares was decidedly higher than the values reported by aforementioned authors. From among protein fractions of mare colostrum and milk, immunoglobulin concentrations are examined most frequently. WŁODARCZYK-SZYDŁOWSKA et al. (2005) determined mean immunoglobulin concentration in mare colostrum directly after parturition at a mean level of $58.8 \%$, which is a higher value than that presented in Table 1 for the colostrum collected $24 \mathrm{~h}$ after foaling. PASQUINI et al. (2005) and TISHNER et al. (1996) observed a significant decrease in the immunoglobulin content in mare colostrum during $12 \mathrm{~h}$ after parturition. In the study of aforementioned authors, the level of immunoglobulin amounting to $110.7 \mathrm{~g} / \mathrm{l}$ after birth - decreased to $20.6 \mathrm{~g} / \mathrm{l} 24 \mathrm{~h}$ after foaling. In the present study, immunoglobulin concentration in the colostrum collected in the same time was higher and amounted to $50.1 \mathrm{~g} / \mathrm{l}$ on average (44.16\%). MALACARNE et al. (2002), basing on the research of other authors, reported that the level of immunoglobulins in mare milk amounts on the average to $19.77 \%$. This is a similar value to that found in the present study in the 1st month of lactation. As it is seen in Table 1, this value decreased gradually during lactation. In the present study, a higher mean concentration of albumins in the colostrum of mares was found than that reported by WŁODARCZYK-SZYDŁOWSKA et al. (2005), who determined it at $14.5 \%$ on average. The mean concentration of aglobulins in our study was almost 2 times lower, while that of $\beta$-globulins was similar to that obtained by the aforementioned authors.

The concentration of all elements (Table 2) decreased in the 1st month of lactation, with differences in case of $\mathrm{Mg}$ and $\mathrm{Zn}$ being confirmed statistically $(P \leq 0.05)$. This corroborates the opinion of TISCHNER et al. (1997) that macro- and microelement concentrations in mare colostrum are higher than in their milk. The aforementioned authors determined the content of $\mathrm{Ca}$ in mare colostrum at $709.4 \mathrm{mg} / \mathrm{l}$, whereas that in milk at $336.67 \mathrm{mg} / \mathrm{l}$. These results are considerably lower than those obtained in the present study. CSAPÓ-KISS et al. (1995) and MARTUZZI et al. (1997) reported that the 
content of Ca in mare milk ranged from 485 to $1355 \mathrm{mg} / \mathrm{kg}$, observing at the same time its decrease during lactation. The aforementioned authors observed large individual differences between samples (660-1670mg/kg). Higher milk Ca concentration, than that presented in Table 2, was found in Arabian mares in the 1st month of lactation, i.e. $913.5 \mathrm{mg} / \mathrm{kg}$ (PIESZKA 2005), and in Italian Saddle Horse mares within the whole lactation, i.e. $1065 \mathrm{mg} / \mathrm{kg}$ (MARTUZZI et al. 1997). CSAPÓ-KISS et al. (1995) reported that $\mathrm{Mg}$ concentration in mare milk can amount to 29 to $118 \mathrm{mg} / \mathrm{kg}$. The $\mathrm{Mg}$ concentrations in the milk of mares in respective lactation months (Table 2) are within the given range, except for that in the colostrum, which was higher. Mean Mg concentration in the milk of Arabian mares in the 1st month of lactation found by PIESZKA (2005) amounted to 95.86 $\mathrm{mg} / \mathrm{kg}$, while that in the milk of Italian Saddle mares found by MARTUZZI et al. (1997) to $76 \mathrm{mg} / \mathrm{kg}$. The authors observed a decrease of those elements during lactation, like in our study. Mean $\mathrm{Zn}$ concentration in the analysed colostrum significantly $(P \leq 0.05)$ exceeded that in milk in the 1st month of lactation, and no systematic decrease in milk $\mathrm{Zn}$ concentration was observed in next lactation months. KAVAZIS et al. (2002) found that mean $\mathrm{Zn}$ level in colostrum in mare groups fed with mineral supplements amounted on the 1st day after parturition to 2.23 to $3.95 \mathrm{mg} / \mathrm{kg}$ but they did not observe a systematic decrease in mare milk $\mathrm{Zn}$ concentration in next lactation months either, with mean concentration value on lactation day 112 being $1.67 \mathrm{mg} / \mathrm{kg}$. Mean $\mathrm{Zn}$ concentration in milk in our study was similar to that obtained by PIESZKA (2005) in Arabian mares in the 1 st month of lactation, i.e. $2.55 \mathrm{mg} / \mathrm{kg}$.

The obtained results confirm the fact that colostrum is a food of most abundant protein and mineral composition, and the same of high biological value. The 1st month of lactation was the period of most dynamic changes in chemical composition of milk. Total protein concentration was at the same level in the colostrum and in the milk in the 1st lactation month, whereas protein fraction concentrations underwent dynamic changes during the 1st month of lactation, with an increase in albumin and a-globulin concentrations and a decrease of immunoglobulin levels during lactation. When compared to the values determined in the colostrum, the level of a-globulins increased 8 times during lactation, whereas that of immunoglobulins decreased almost 4 times. The highest concentrations of $\mathrm{Ca}, \mathrm{Mg}$ and $\mathrm{Zn}$ were found in mare colostrum, with a decrease in the concentration of all chemical elements in the 1st month of lactation. Small number of reports referring in particular to changes in concentrations of respective protein fractions in mare colostrum and milk inspires, however, to take up further studies in this field.

\section{References}

Csapó-Kiss ZS, Stefler J, Martin TG, Makray S, Csapó J (1995) Composition of mares' colostrum and milk Protein content, amino acid composition and contents of macro- and micro-elements. Int Dairy J 5 , 403-15

Danków R, Pikul J, Wójtowski J, Cais-Sokolińska D (2006) Chemical composition and physicochemical properties of colostrum and milk of Wielkopolska mares. Pol J Natur Sci 20, 147-54

Danków R, Wojtowski J, Pikul J, Niżnikowski R, Cais-Sokolińska D (2006) Effect of lactation on the hygiene quality and some milk physicochemical traits of the Wielkopolski mares. Arch Tierz $49 \mathrm{SI}$, 202-6

Kavazis AN, Kivipelto J, Ott EA (2002) Supplementation of broodmares with copper, zinc, iron, manganese, cobalt, iodine and selenium. J Equ Vet Sci 22, 460-4 
Malacarne M, Martuzzi F, Summer A, Mariani P (2002) Protein and fat composition of maress milk: some nutritional remarks with reference to human and cow's milk. Int Dairy J 12, 869-77

Martuzzi F, Catalano AL, Summer A, Mariani P (1997) Calcium, phosphorus and magnesium in the milk of nursing mares from Italian Saddle Horse breed and their variations during lactation. 48th Annual Meeting of the EAAP, Vienna, 25-28 August 1997, H514

Pasquini M, Tommei B, Trenti G, Falaschini A (2005) Pre-foaling period in Trotter mares-2: variations of protein fractions in pre-colostrum secretion. Ital J Anim Sci 4 Suppl 2, 424-6

Pieszka M (2005) The composition of Arabian mares' milk, http://www.waho.org/History/ ArabianMaresMilk.htm [last accessed 07.01.2008]

Tishner M, Niezgoda J, Wieczorek E, Mękarska A, Lisowska A (1996) The evaluation of mare colostrum quality. Med Weter 52, 381-3 [in Polish]

Włodarczyk-Szydłowska A, Nowacki W, Wierzbicki H (2005) The effect of selected factors on the quality of mare colostrum and the level of colostrum immunoglobulins in foals. Med Weter $61,923-6$ [in Polish]

Received 18 July 2007, accepted 19 December 2008.

Corresponding author:

Dr. ANGELIKA CIEŚLA

email: angelika.ciesla@biot.ar.szczecin.pl

Department of Horse Breeding, West Pomeranian University of Technology, UI. Dr Judyma 24, 71-466 Szczecin, Poland 